\title{
Austrian Macroeconomics in Search of Its Uniqueness
}

\section{William J. Luther}

Kenyon College

\section{J. P. McElyea}

comScore, Inc.

\begin{abstract}
We consider the essential features of an Austrian macroeconomic model and then ask whether these features are unique. We argue that the temporal aspect of the structure of production is not an essential feature. Malinvestments in any dimension (e.g., time, geography, type, etc.) can generate the predicted boom-bust cycle so long as there are costs to reallocation. However, the view that nominal shocks have long-term consequences because costs are incurred to remedy past mistakes is not uniquely Austrian. In particular, we note similarities with the New Keynesian notion of hysteresis.
\end{abstract}

JEL Codes: B53, E10, E14, E30, E32

Keywords: Austrian business cycle, Austrian macroeconomics, business cycle, macroeconomics, macroeconomic fluctuation

\section{Introduction}

Austrian macroeconomics is experiencing a revival. Some scholars have used the Austrian business cycle theory to explain the Great Recession (O’Driscoll 2009; White 2009; Boettke and Luther 2010; Horwitz and Luther 2011; Koppl 2014). Others have employed Austrian insights to consider the effectiveness of monetary and macroprudential policies (Garrison 2009; White 2010; Selgin 2010; Salter 2016; Salter and Smith 2017; Salter and Tarko 2017). Moreover, as Koppl and Luther (2012) and Cachanosky and Salter (2017) make clear, these efforts have not been limited to self-ascribed Austrians.

Given the renewed interest, we consider the essential features of an Austrian macroeconomic model and then ask whether these features are unique. We argue that the temporal aspect of the 
structure of production is not an essential feature. Malinvestments in any dimension (e.g., time, geography, type, etc.) can generate the predicted boom-bust cycle so long as there are costs to reallocation. However, the view that nominal shocks have long-term consequences because costs are incurred to remedy past mistakes is not uniquely Austrian. In particular, we note similarities with the New Keynesian notion of hysteresis.

\section{Essential Features}

What is Austrian macroeconomics? In any progressive research program, one will find disputes over what it means to be working in a particular tradition and what distinguishes the in-group from the outgroup. Austrian macroeconomics is no different in that respect. One might use the term to refer exclusively to the historical Austrian business cycle theory advanced by Mises (1912) and Hayek (1935). Others might use it to denote a more modern variation, which Garrison (2005) has called "capital-based macroeconomics." Still others refer to a "new Austrian" or "neo-Mengerian" macroeconomics (Salter 2017; Wagner 2007, 2010, 2012).

We use the term Austrian macroeconomics to denote a class of models that account for macroeconomic fluctuation in a way that is broadly consistent with (but not defined by) the views put forward by Ludwig von Mises and F. A. Hayek. The class of models we have in mind includes the traditional Austrian business cycle theory (e.g., Hayek 1935) as well as modern restatements (e.g., Garrison 1984, 2002; Horwitz 2002). More generally, it includes any model with the following essential features:

- microfoundations

- monetary non-neutrality

- capital specificity and the potential for malinvestment

- costly errors

We discuss each in turn.

\section{A. Microfoundations}

Methodological individualism has been a central tenet of Austrian economics since its founding - and this approach is no less necessary in the domain of macroeconomics. Individuals acquire information,

\footnotetext{
${ }^{1}$ We are not interested in settling claims to the Austrian label. Instead, we simply specify what we mean by the term "Austrian macroeconomics" and leave others to decide whether to adopt our nomenclature.
} 
devise plans, and make decisions. They might coordinate their actions in households or firms. Nonetheless, the individual is the ultimate unit of analysis, and understanding why individuals do this or thatwhat is sometimes referred to as the deep parameters of the modelis essential for assessing the welfare consequences of a given shock or policy response (Lucas 1976). As such, macroeconomic models in the Austrian tradition must be based on microeconomic foundations.

In advocating the need for microfoundations, some Austrians have taken a hard stand against aggregate or representative agent models. Bagus and Howden (2012, p. 274) claim that a majority of "errors stem from a too aggregative approach to economic theory" and dependence on "the Keynesian terminology of 'aggregate demand'." They echo Hayek's (1931) concern that "Mr. Keynes' aggregates conceal the most fundamental mechanisms of change." Others have stressed the need for heterogeneous agent models and a corresponding refocus on the interactions between agents (e.g., Koppl 2011; Wagner 2012). ${ }^{2}$ Such views would seem to imply that microfoundations are necessary but not sufficient; that a specific type of microfoundations is required.

We do not go so far. Rather, we maintain that a good model identifies a specific and potentially significant mechanism in a clear and concise way. The relevant question is not whether aggregate or representative agent models are appropriate. Instead, one should be concerned with the appropriate level of aggregation or the appropriate degree of heterogeneity given the task at hand. For example, White and Selgin (2017) depict the Austrian business cycle theory using the standard textbook aggregate demand-aggregate supply framework, where the microfoundations are implicit but fairly well understood. Given their objective, the aggregate model seems appropriate. ${ }^{3}$ This is not to deny that excessive aggregation might lead one to inappropriate conclusions or that important details are glossed over when agents are assumed to be homogeneous. It is merely to acknowledge that a simple model is, in some cases, sufficient to make one's point.

A related issue concerns the behavioral and epistemic assumptions of agents populating Austrian macroeconomic models-specifically, whether they should be assumed to have

\footnotetext{
2 Bilo (2017b) focuses on interaction and describes economic activity as "a stream of interconnected experiments, where some entrepreneurial experiments are bound to fail." See also DeGrauwe (2010).

3 See also Salter (2013).
} 
rational expectations. Bilo (2017c) summarizes the debate. On the one hand, we reject the assertion that an Austrian theory of macroeconomic fluctuation necessarily "conflicts with the rational expectations" assumption (Bilo 2017c, p. 14). Salter and Luther (2016) offer an Austrian business cycle model where agents have rational expectations. ${ }^{4}$ On the other hand, we do not believe Austrian macroeconomics is "bound to remain on the fringe of discussions among professional economists" unless rational expectations are adopted (Bilo 2017c, p. 21). As Reis (2017, p. 21) makes clear, mainstream macroeconomists "have made much progress in the last three decades to provide alternatives to the assumptions of [...] rational expectations." As such, we view the rational expectations assumption as an optional feature of Austrian macroeconomic models.

\section{B. Monetary Non-Neutrality}

Modern macroeconomists can be crudely divided into two camps: those who maintain that macroeconomic fluctuation is driven entirely by real shocks and those who leave some scope for nominal shocks. The Austrians are firmly in the latter camp. ${ }^{5}$ Austrians maintain that money is non-neutral: nominal shocks have real consequences.

Belief in the non-neutrality of money is not particularly alienating in the economics profession today. Most modern macroeconomists accept that money is non-neutral in the short run. In standard textbook models, agents face a signal-extraction problem (Lucas 1972; Sargent 1991) or are subject to information cascades (Mankiw and Reis 2002, 2007) or find it prohibitively costly to collect information and update prices instantaneously (Alchian 1969) or encounter some other friction that enables real disturbances from nominal shocks. These mechanisms for generating non-neutrality seem entirely consistent with Austrian macroeconomics. ${ }^{6}$

\footnotetext{
${ }^{4}$ Cachanosky (2015) and Carilli and Dempster (2001) also address the expectations issue.

5 White (2016) considers Hayek's relationship to contemporary macroeconomics.

6 This should not be surprising. Lucas (1981, p. 216) once remarked that "the most rapid progress toward a coherent and useful aggregate economic theory will result from [. . .] a resumption of the work of pre-Keynesian theorists" and "many modern economists would have no difficulty accepting Hayek's statement of the problem as roughly equivalent to their own." Whether consciously or unconsciously, many modern macroeconomists have followed up on his suggestion.
} 
To the extent that Austrians part ways with the bulk of the profession on the non-neutrality of money, it is with regard to the time horizon over which non-neutrality prevails. Most macroeconomists accept that money is neutral—or, approximately neutral - in the long run. Austrians, in contrast, argue that money is non-neutral in the long run. Bilo (2017d, 2017f) and Bilo and Wagner (2015) have revived the ideas of the sixteenth-century economist Richard Cantillon in noting that monetary disturbances alter individual decisions and, as such, affect the resulting distribution of wealth. ${ }^{7}$ Hence, money has lasting effects. In the model put forward below, we go further in arguing that monetary shocks also affect the equilibrium (or, natural) path of real output in the long run. In any event, we maintain that an Austrian macroeconomic model must acknowledge some potential for monetary non-neutrality.

\section{Capital Specificity and the Potential for Malinvestment}

Austrian macroeconomics developed, in part, as an extension of Austrian capital theory, which took it for granted that capital was specific to particular production processes. If capital were homogeneous, one need only consider whether individuals accumulate the optimal amount of capital, or, alternatively, whether they might be induced to accumulate too much or too little capital. In asserting the specificity of capital, Austrians accept that there is an optimal composition of capital: that it is possible to have too much of one kind of capital and too little of another. In other words, Austrian macroeconomists are not merely concerned with the prospect of over- and underinvestment, but also with malinvestment.

Historically, Austrians have emphasized the temporal dimension of production and, correspondingly, the prospect for malinvestment to occur over the time structure of production (e.g., Hayek 1935; Garrison 2002; Bilo 2017a, 2017e). By pushing real interest rates below their equilibrium values, the familiar Austrian story goes, an unexpected monetary shock induces entrepreneurs to invest more heavily in the earliest and latest stages of production at the expense of middle-stage investments. "Attention to the time element in the process of production and, more specifically, the incorporation of an intertemporal capital structure," Garrison (1991, p. 303) writes, "are

\footnotetext{
${ }^{7}$ Luther and Salter (2012) question the relevance of Cantillon effects.

8 Garrison (2005) explains that the time discount effect encourages investment in the earliest stages, whereas the derived demand effect encourages investment in the latest stages. Both effects are relatively weak for middle-stage investments.
} 
what characterize Austrian macroeconomics and set it apart from the more widely accepted formulations of macroeconomic relationships." Indeed, recent efforts to revise Austrian capital theory continue to assert that the temporal dimension is key (Braun, Lewin, and Cachanosky 2016; Lewin and Cachanosky 2016, forthcoming a, b).

We do not deny that the time structure of production might become distorted. However, we maintain that the concept of malinvestment is not limited to the temporal dimension. Just as individuals might accumulate capital for producing goods in the early or late stages of the production process, they also accumulate capital in a specific place, for a specific industry, for a specific quality of production, and so on. In other words, capital is specific in many ways and, therefore, malinvestment might occur along many dimensions. It is not at all obvious why one of these dimensions should be considered more relevant to questions of macroeconomic discoordination a priori.

Expanding the concept of malinvestment is not only theoretically sound, but also empirically warranted since the economic significance of malinvestment in the temporal dimension is unclear. Lucas (1981) famously noted that the interest-elasticity of investment is too small to account for the historically observed cyclical variation in investment. ${ }^{9}$ More recent studies find little support that production in early and late stages expands relative to middle-stage production in response to positive monetary shocks (Lester and Wolff 2013; Luther and Cohen 2014). However, as Luther and Cohen (2016) point out, the data employed in those studies fail to measure production at given temporal distances from consumption as a proper empirical assessment would require. Young (2012) finds changes in the time structure of production consistent with the traditional Austrian view over the period from 2002 to 2008. ${ }^{10}$ Likewise, Cachanosky (forthcoming), Cachanosky and Lewin (2014, 2016a, 2016b), and Lewin and Cachanosky (2016) find support for temporal distortions by exploiting the Macaulay duration. Given the mixed empirical evidence and the difficulty of assessing temporal distortions, we believe Austrians would do well to consider malinvestments made along other dimensions.

Finally, it is worth noting that malinvestment is not limited to physical capital. Individuals might accumulate what is later revealed

\footnotetext{
9 As White (2016) points out, Lucas made no effort to support his claim.
}

10 See also Keeler (2001) and Young (2011). 
to be the wrong type of human capital; or, they might fail to accumulate human capital when doing so would make them better off. Bellante (1983, 1994), Boettke, Luther, and Stein (forthcoming), and Horwitz (2010) acknowledge labor specificity and the potential for malinvestments in labor markets. Young (2005) considers whether labor moves when the capital structure adjusts. Similarly, Schaffer (forthcoming) presents response functions for employment and earnings in ten sectors following a monetary policy shock.

\section{Costhy Errors}

When it is realized that the wrong types of physical or human capital have been accumulated, resources must be reallocated. Machines are auctioned off or retooled or broken down into component pieces and used to produce or repair other machines. They are moved from one location to another. Workers must retrain or relocate or both. Reallocating capital along these lines is costly. And, since physical and human capital are specific, the costs of reallocation can be significant. Austrian macroeconomic models must take these costs into account.

Austrians are usually quick to point out that malinvestments are made during an unsustainable boom, necessitating a costly recovery during which capital and labor are reallocated. Traditionally, they have been less keen to acknowledge the real costs of errors when the economy is underproducing. When too little is produced, there is correspondingly too little set aside for future production: fewer resources are used to accumulate capital and to engage in research and development. Resources left in the ground or unrefined are no less malinvested than those that are in the wrong region or factory. On-the-job training does not take place when folks are not on the job; skills atrophy and, in some cases, become obsolete. Workers who fail to acquire skills on pace have the wrong skills in much the same way as one who acquired skills that turn out to be less valuable than expected. Ideas that are not discovered today might be discovered tomorrow. But the additional production, capital accumulation, and ideas that would have been possible had those discoveries been made are all similarly pushed into the future. In short: time wasted is not easily made up. Just as it is costly to reallocate existing malinvestments from errors of commission, it is also costly to make up for errors of omission. And just as some malinvestments are unrecoverable, so too are some of the unrealized gains discussed above. Austrian macroeconomic models should incorporate the costs that are incurred when the composition of production deviates from 
the ideal, regardless of whether those costs stem from actions that were taken or actions that were foregone.

\section{General Model and Implications}

Austrian macroeconomic models have much in common with the standard textbook business cycle model. Both stress the importance of microfoundations and accept that unexpected monetary shocks will have real effects. There are significant differences, though. Specifically, Austrians stress the specificity of capital and the corresponding importance of the composition of production. As such, errors are costly.

In what follows, we offer a simple, stylized model to clarify the differences between Austrian macroeconomics and the standard textbook model. ${ }^{11}$ The model we present is similar in most respects to Lucas (1975). ${ }^{12}$ As such, we rely on standard microfoundations and only present the equations governing the macroeconomy. Two specifications of the model are considered. In the standard textbook specification, resources can be reallocated without cost. In the Austrian specification, errors are costly. We trace the effects of positive and negative monetary shocks under both specifications.

\section{A. The Model}

The monetary authority aims to promote monetary equilibrium. It does so by expanding and contracting the supply of money to stabilize the growth path of nominal spending. Let $N_{t}=P_{t} Y_{t}$ denote nominal income in the economy at time $t$, where $P_{t}$ and $Y_{t}$ refer to the price level and real output, respectively. Suppose $m$ is the nominal income growth factor consistent with the optimal growth path of nominal income. As such, the monetary authority targets a level of nominal income equal to $\widehat{N}_{t}=m \widehat{N}_{t-1}$.

11 We do not wish to imply that our model is canonical or that other, more rigorous models (e.g., Honing et al. 2017) should be rejected out of hand due to their complexity. We merely hope to convey the principal differences between the ABCT and standard textbook model and have selected the simplest model possible to make these differences clear. Cachanosky and Padilla (2016) provide a comparable model that emphasizes the temporal dimension. See also Hendrickson and Salter (2016).

12 There are essentially two differences. First, whereas agents in Lucas (1975) form expectations over the price level, agents in our model form expectations over the level of nominal income. As such, the price level is endogenous in our model, whereas the level of nominal income is endogenous in Lucas (1975). Second, we allow past mistakes to affect potential output. 
What does the monetary authority do if it misses its target? We use the parameter $\mu$ to denote the speed with which the monetary authority corrects course, where $0<\mu<1$. A higher value of $\mu$ reflects a faster return to the target path. ${ }^{13}$ Given $\mu$ and the monetary authority's ability to achieve its target in the long run, the nominal income at time $t$ can be expressed as $N_{t}=m\left[N_{t-1}+\mu\left(N_{t-1}-\right.\right.$ $\left.\widehat{N}_{t-1}\right){ }^{14}$

Potential real output depends on total factor productivity growth and the extent to which resources have been utilized effectively in the past. Suppose $g$ is the real output growth factor consistent with growth in total factor productivity. We use the parameter $\rho$ to denote the extent to which errors (i.e., over- or underproduction) affect potential real output, where $0 \leq \rho \leq 1$. When $\rho=0$, past errors have no effect on potential real output. When $\rho=1$, past errors are completely irrecoverable; they reduce potential real output by the magnitude of the error. Hence, potential real output at time $t$ can be written as $\bar{Y}_{t}=g\left[\bar{Y}_{t-1}-\rho\left|\bar{Y}_{t-1}-Y_{t-1}\right|\right]$.

Individuals wish to produce the level of real output consistent with long-run economic growth. However, they face a signalextraction problem. When they observe others intent on increasing nominal expenditures for the products they sell, they do not know whether this behavior represents an increase in aggregate demand or an increase in the relative demand for their products. We use the parameter $\sigma$ to express how responsive the representative agent is to nominal shocks, where $0<\sigma<1$. Hence, real output at time $t$ can be expressed as $Y_{t}=\bar{Y}_{t}+\sigma\left(N_{t}-\widehat{N}_{t}\right)$.

We assume individuals have rational expectations. They are not systematically fooled by monetary policy. Rather, they face a signalextraction problem. As such, unexpected deviations from the target path of nominal income generate real production errors. These errors, in turn, reduce the long-run path of potential real output.

\footnotetext{
13 It takes time to collect and analyze data, formulate an appropriate response, and engage in open-market operations. One might think of $\mu$ as accounting for these standard lags in monetary policy.

${ }^{14}$ Given the equation, our specification of $0<\mu<1$ should be clear. If $\mu<0$, the monetary authority would establish a level of nominal income further away from the target path each period; $\mu=0$ amounts to growth rate targeting; $\mu>1$ would denote a monetary authority that consistently overreacts.
} 


\section{B. Monetary Shocks}

To compare the effects of an unexpected monetary shock predicted by Austrian macroeconomic and standard textbook models, we specify two parameterizations of the model and then trace the corresponding stylized impulse-response functions. ${ }^{15}$ The specific parameterizations are presented in table 1 . The crucial difference concerns the extent to which errors are costly. For the Austrian specification, $\rho=0.02$. For the standard textbook specification, $\rho=$ 0.

\begin{tabular}{ccc}
$\begin{array}{c}\text { Table 1. Two Parameterizations of the Model } \\
\text { Parameters }\end{array}$ & Standard & Austrian \\
\hline$m$ & 1.04 & 1.04 \\
$\mu$ & 0.20 & 0.20 \\
$g$ & 1.02 & 1.02 \\
$\rho$ & 0.00 & 0.02 \\
$\sigma$ & 0.99 & 0.99
\end{tabular}

Stylized impulse-response functions for positive and negative monetary shocks under both parameterizations are included in figures 1 and 2, respectively. The standard textbook model is considered in panel A. The Austrian macroeconomic model is considered in panel $\mathrm{B}$.

Following a positive monetary shock, real output increases under both parameterizations as individuals are temporarily fooled into overproducing. In the standard textbook model, these errors have no effect on potential output. As such, the economy gradually returns to its long-run potential, which corresponds to the initial trend line.

In the Austrian macroeconomic model, in contrast, errors are costly. As individuals overproduce, potential output declines. As such, when the economy gradually returns to its long-run real output growth path, that growth path lies below the initial trend line.

\footnotetext{
15 We use fixed parameters merely to offer pattern predictions. We do not contend that a given set of parameters holds for all times and all places. For example, Lucas (1973) shows that individuals producing in stable monetary regimes are prone to make larger errors in the event of a monetary shock than those in less stable monetary regimes. Hence, $\sigma$ might vary across countries. Likewise, $\rho$ might differ over time or depend on the sign of the monetary shock; $g$ might be stochastic; etc.
} 
Figure 1. Positive Monetary Shock
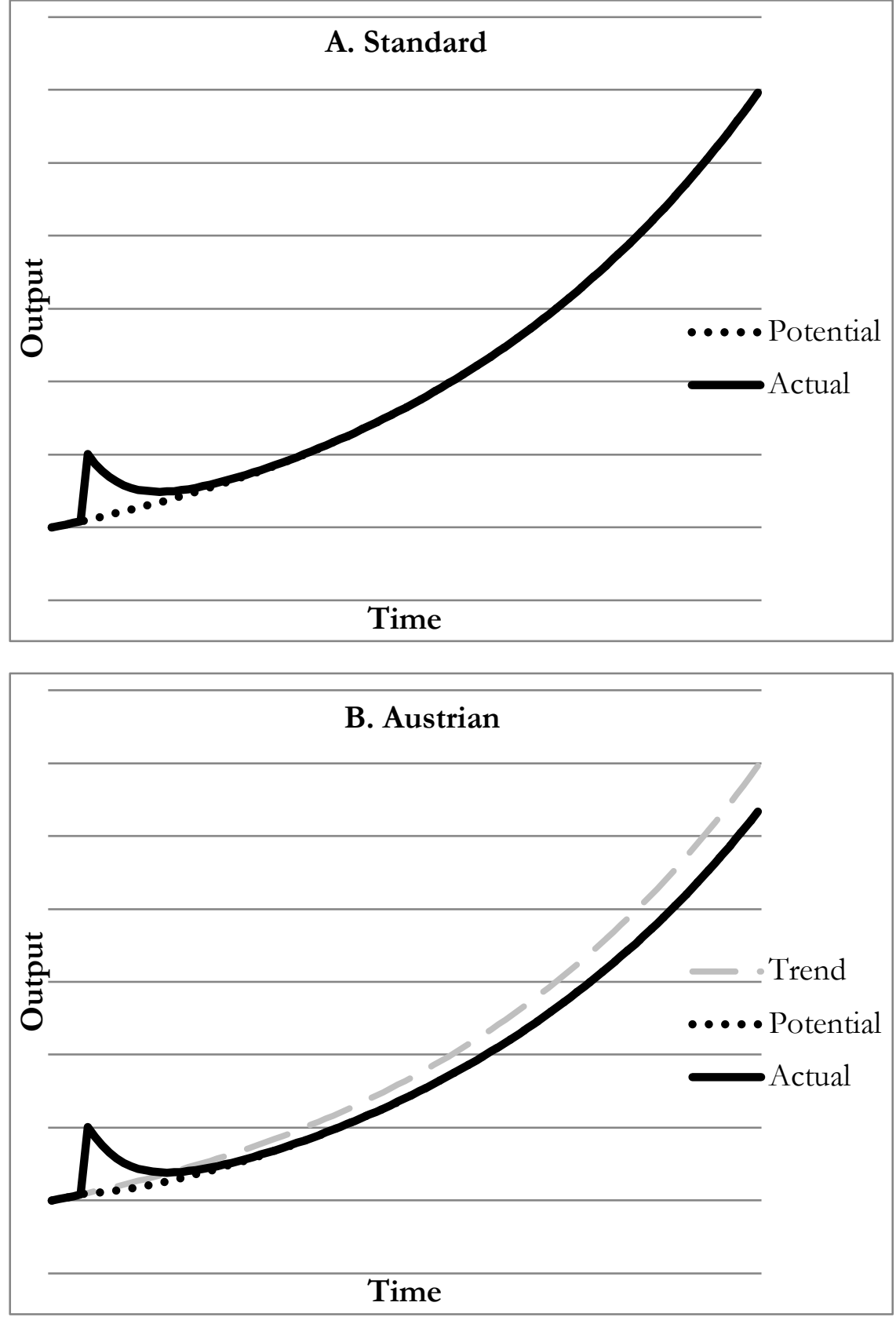
Figure 2. Negative Monetary Shock
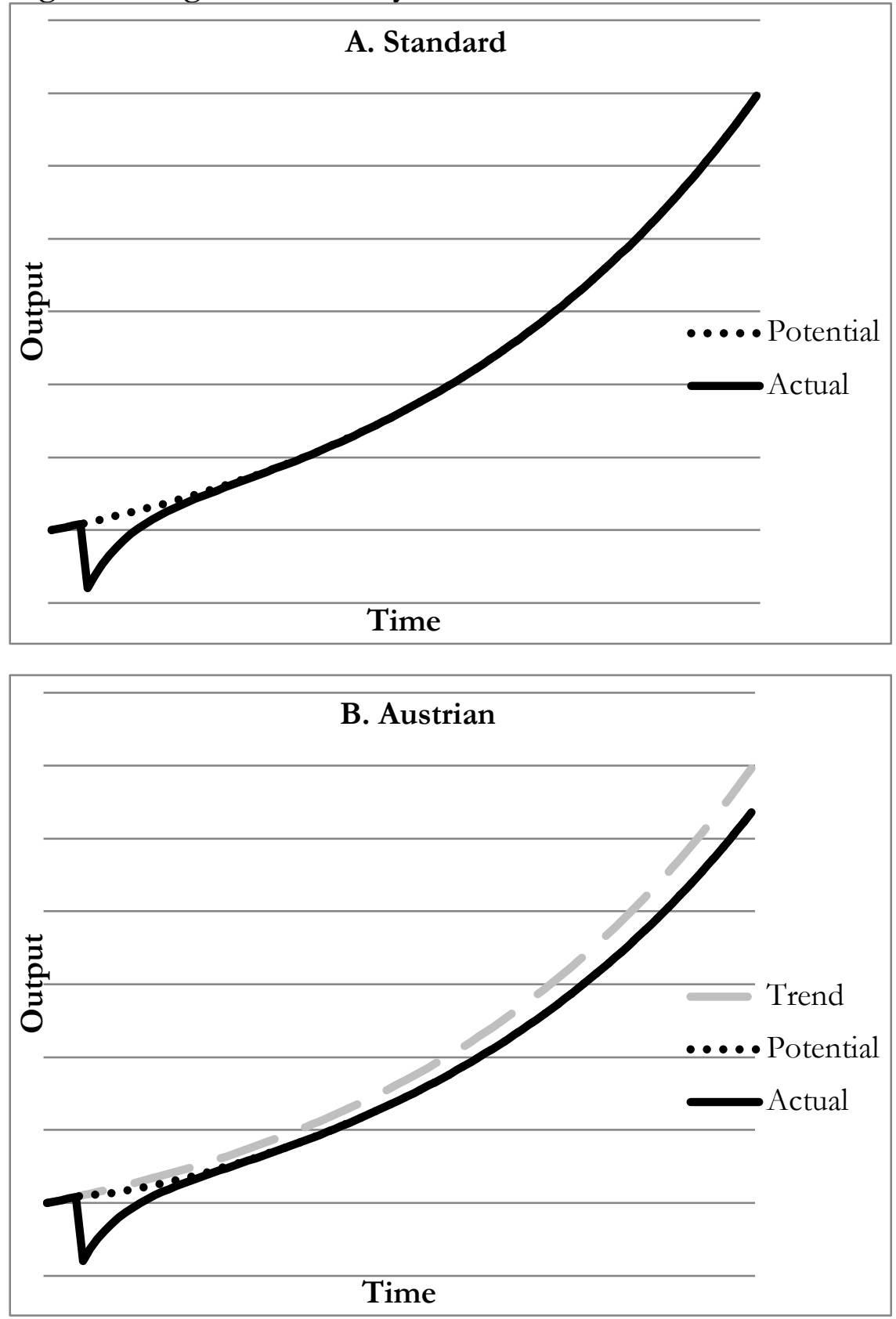

Following a negative monetary shock, real output decreases under both parameterizations as individuals are temporarily fooled into underproducing. As in the case of overproducing, these errors have 
no effect on potential output in the standard textbook model. The economy gradually returns to its long-run potential, which corresponds to the initial trend line. ${ }^{16}$ However, these errors reduce potential output in the Austrian macroeconomic model, meaning that, when the economy returns to its long-run real output growth path, that growth path lies below the initial trend line.

\section{Are Costly Errors Uniquely Austrian?}

We have argued that Austrian macroeconomics differs from the standard textbook business cycle model in maintaining that errors are costly. The inclusion of costly errors follows, at least in part, from the Austrian position that physical and human capital are specific. As shown above, the inclusion of costly errors generates predictions distinct from the standard textbook model. With this in mind, we next consider whether the inclusion of costly errors is a uniquely Austrian approach.

While the view that costs are incurred to remedy past mistakes is essential to Austrian macroeconomics, it is not unique. It is similar in some respects to the New Keynesian notion of hysteresis. In general, hysteresis refers to the idea that the long-run equilibrium depends (at least in part) on the transition path taken to reach it (Phelps 1972). Early efforts focused primarily on the effect of recessions on the natural rate of unemployment (e.g., Hargreaves Heap 1980). More recent efforts have broadened the idea to include long-run effects on productivity and, hence, real output growth (e.g., Summers 2014).

The idea of hysteresis came to prominence in the 1980s, following sharp increases in unemployment rates (especially in Europe) in the $1970 \mathrm{~s}$ and $80 \mathrm{~s}^{17}$ Blanchard and Summers (1986, 1987) showed that recessions could have lasting effects on the natural rate of unemployment in an insider-outsider model. ${ }^{18}$ Others stressed that the natural rate of unemployment might increase as prolonged periods of unemployment reduce work ethic, erode human capital, or prompt the enactment of labor-reducing policies (Clark and Summers

\footnotetext{
16 When limited to negative monetary shocks, the standard textbook model resembles Friedman's (1993) plucking model. See also Garrison (1996) and Kim and Nelson (1999).

17 Blanchard and Summers (1988) offer an early survey of the literature. See also Cross (1993) and O’Shaughnessy (2011).

18 Layard and Nickell (1985, 1986, 1989), Nickell (1990), and Layard, Layard, and Nickell (1991) also stressed the insider-outsider nature of wage setting and, in particular, the role of unions.
} 
1982; Sessions 1994; Möller 1990; Price 1992; Di Tella and MacCulloch 2006; Minford and Naraidoo 2010; Blanchard and Wolfers 2000; Blanchard 2005). Rowthorn (1995) explains that capital formation might generate unemployment hysteresis. Ball (1999, 2009), Stockhammer and Sturn (2012), and Sturn (2012) consider the relationship between monetary policy conducted in a recession and the equilibrium rate of unemployment.

More recently, attention has turned to hysteresis in real output. Summers (2014, p. 66) provides a clear statement: "it is increasingly clear that the trend in growth can be adversely affected over the longer term by what happens in the business cycle." ${ }^{19}$ DeLong and Summers (2012) offer an explicit aggregate model, where potential output depends on past divergences from potential, and discuss the mechanisms determining the hysteresis parameter. Moreover, the long-run consequences of short-run disturbances appear to be nontrivial. Cerra and Saxena (2008, p. 456) estimate persistent output losses ranging from 4 percent to 16 percent over a ten-year horizon.

These efforts suggest potential inroads for those working in the Austrian tradition. To be sure, there are significant differences between our conception of Austrian macroeconomics and the hysteresis found in recent New Keynesian models. For example, the model put forward by DeLong and Summers (2012) suggests that a period of overproduction would generate positive hysteresis effects. Nonetheless, the general idea-that errors today have long-term consequences-and some of the specific mechanisms, such as "reduced labor force attachment on the part of the long-term unemployed, scarring effects on young workers who have trouble beginning their careers, $[\ldots]$ reduced investment in $[\ldots]$ research and development and in physical capital, reduced experimentation with business models and informational spillovers, and changes in managerial attitudes" (DeLong and Summers 2012, p. 254)—seem entirely consistent with the view of Austrian macroeconomics outlined earlier.

\section{Conclusion}

With renewed interest in Austrian macroeconomics, it is important to identify its essential features. We maintain that an Austrian macroeconomic model must be based on microfoundations; provide

19 Summers cites as evidence the 5 percent decline in the Congressional Budget Office's estimate of potential GDP following the Great Recession. 
scope for monetary non-neutrality; recognize capital specificity and the potential for malinvestment; and acknowledge that errors are costly. In doing so, we part ways with other Austrians by arguing that the temporal aspect of the structure of production is not an essential feature. Malinvestments in any dimension (e.g., time, geography, type, etc.) are sufficient so long as there are costs to reallocation.

We have offered a simple model to demonstrate the significance of costly errors. Whereas nominal shocks in the standard textbook model result in temporary deviations and an ultimate return to trend, those same shocks in an Austrian macroeconomic model generate costly errors, reducing potential output in the future. We have discussed the similarities between our approach and New Keynesian models with hysteresis, which are also on the rise. We suggest that self-ascribed Austrians build on the hysteresis literature explicitly.

\section{References}

Alchian, Armen A. 1969. "Information Costs, Pricing and Resource Unemployment." Economic Inquiry, 7(2): 109-28.

Bagus, Philip, and David Howden. 2012. "Monetary Equilibrium and Price Stickiness: A Rejoinder." Review of Austrian Economics, 25(3): 271-77.

Ball, Lawrence. 1999. "Aggregate Demand and Long-Run Unemployment." Brookings Papers on Economic Activity, 2: 189-236.

Ball, Lawrence. 2009. "Hysteresis in Unemployment: Old and New Evidence." National Bureau of Economic Research Working Paper No. 14818.

Bellante, Don. 1983. "A Subjectivist Essay on Modern Labor Economics." Managerial and Decision Economics, 4(4): 234-43.

Bellante, Don. 1994. "Labor Economics." In The Elgar Companion to Austrian Economics, ed. P. J. Boettke, 258-63. Cheltenham, UK: Edward Elgar.

Bilo, Simon. 2017a. "Austrian Calculus: Interest Rate and Allocation of Capital." Working paper.

Bilo, Simon. 2017b. "Entrepreneurial Errors in a Kaleidic Democracy." Journal of Private Enterprise, 33(2).

Bilo, Simon. 2017c. "Hayek's Theory of Business Cycles: Theory That Will Remain Obscure." Working paper.

Bilo, Simon. 2017d. "How Cantillon and Hume Propose the Same Theory of FirstRound Effects." Working paper.

Bilo, Simon. 2017e. "Intertemporal Capital Substitution and Hayekian Booms." Working paper.

Bilo, Simon. 2017f. "Lucas and Hume on Monetary Non-Neutrality: A Tension between the Logic and the Technique of Economics." Working paper.

Bilo, Simon, and Richard E. Wagner. 2015. "Neutral Money: Historical Fact or Analytical Artifact?" Review of Austrian Economics, 28(2): 139-50.

Blanchard, Olivier. 2005. "European Unemployment: The Evolution of Facts and Ideas.” NBER Working Paper No. 11750. 
Blanchard, Olivier J., and Lawrence H. Summers. 1986. "Hysteresis and the European Unemployment Problem." In NBER Macroeconomics Annual, vol. 1, ed. Stanley Fischer, 15-90. Cambridge, MA: MIT Press.

Blanchard, Olivier J., and Lawrence H. Summers. 1987. "Hysteresis in Unemployment.” European Economic Review, 31(1-2): 288-95.

Blanchard, Olivier J., and Lawrence H. Summers. 1988. "Beyond the Natural Rate Hypothesis." American Economic Review, 78(2): 182-87.

Blanchard, Olivier, and Justin Wolfers. 2000. "The Role of Shocks and Institutions in the Rise of European Unemployment: The Aggregate Evidence." Economic Journal, 110 (March): C1-C33.

Boettke, Peter J., and William J. Luther. 2010. "The Ordinary Economics of an Extraordinary Crisis." In Macroeconomic Theory and Its Failings: Alternative Perspectives on the World Financial Crisis, ed. Steven Kates, 14-25. Cheltenham, UK: Edward Elgar.

Boettke, Peter J., William J. Luther, and Solomon Stein. Forthcoming. "Labor Economics from an Austrian Perspective." In Models of Labor Markets, ed. Bruce Kaufman. Stanford, CA: Stanford University Press.

Braun, Eduard, Peter Lewin, and Nicolás Cachanosky. 2016. “Ludwig von Mises’s Approach to Capital as a Bridge between Austrian and Institutional Economics." Journal of Institutional Economics, 12(4): 847-66.

Cachanosky, Nicolás. 2015. "Expectations in Austrian Business Cycle Theory: Market Share Matters." Review of Austrian Economics, 28(2): 151-65.

Cachanosky, Nicolás. Forthcoming. "Austrian Economics, Market Process, and the EVA ${ }^{\circledR}$ Framework." Journal of Business V aluation and Economic Loss Analysis.

Cachanosky, Nicolás, and Peter Lewin. 2014. "Roundaboutness Is Not a Mysterious Concept: A Financial Application to Capital Theory." Review of Political Economy, 26(4): 648-65.

Cachanosky, Nicolás, and Peter Lewin. 2016a. "An Empirical Application of the EVA $^{\circledR}$ Framework to Business Cycles." Review of Financial Economics, 30 (September): 60-67.

Cachanosky, Nicolás, and Peter Lewin. 2016b. "Financial Foundations of Austrian Business Cycle Theory." Advances in Austrian Economics, 20:15-44.

Cachanosky, Nicolás, and Alexandre Padilla. 2016. "A Mathematical Version of Garrison's Model.” Quarterly Journal of Austrian Economics, 19(3): 225-47.

Cachanosky, Nicolás, and Alexander W. Salter. 2017. "The View from Vienna: An Analysis of the Renewed Interest in the Mises-Hayek Theory of the Business Cycle." Review of Austrian Economics, 30(2): 169-92.

Carilli, Anthony M., and Gregory M. Dempster. 2001. "Expectations in Austrian Business Cycle Theory: An Application of the Prisoner's Dilemma." Review of Austrian Economics, 14(4): 319-30.

Cerra, Valerie, and Sweta C. Saxena. 2008. "Growth Dynamics: The Myth of Economic Recovery." American Economic Review, 98(1): 439-57.

Clark, Kim, and Lawrence H. Summers. 1982. "Labor Force Participation: Timing and Persistence." Review of Economic Studies, 49: 825-44.

Cross, Rod. 1993. "On the Foundations of Hysteresis in Economic Systems." Economics and Philosophy, 9(1): 53-74.

DeGrauwe, Paul. 2010. "The Scientific Foundation of Dynamic Stochastic General Equilibrium (DSGE) Models." Public Choice, 144(3-4): 413-43. 
DeLong, J. Bradford, and Lawrence H. Summers. 2012. "Fiscal Policy in a Depressed Economy.” Brookings Papers on Economic Activity, Spring: 23374.

Di Tella, Rafael, and Robert MacCulloch. 2006. "Europe vs. America: Institutional Hysteresis in a Simple Normative Model." Journal of Public Economics, 90(12): 2161-86.

Friedman, Milton. 1993. "The 'Plucking Model' of Business Cycle Fluctuations Revisited." Economic Inquiry, 31(2): 171-77.

Garrison, Roger W. 1984. "Time and Money: The Universals of Macroeconomic Theorizing." Journal of Macroeconomics, 6(2): 197-213.

Garrison, Roger W. 1991. "Austrian Capital Theory and The Future of Macroeconomics." In Austrian Economics: Perspectives on the Past and Prospects for the Future, ed. R. M. Ebeling, 303-24. Hillsdale, MI: Hillsdale College Press.

Garrison, Roger W. 1996. “Friedman's 'Plucking Model': Comment." Economic Inquiry, 34(4): 799-802.

Garrison, Roger W. 2002. Time and Money: The Macroeconomics of Capital Structure. London: Routledge.

Garrison, Roger W. 2005. "The Austrian School: Capital-Based Macroeconomics." In Modern Macroeconomics: Its Origins, Development and Current State, ed. Brian Snowdon and Howard R. Vane, 474-516. Aldershot, UK: Edward Elgar.

Garrison, Roger W. 2009. "Interest-Rate Targeting During the Great Moderation: A Reappraisal." Cato Journal, 29(1): 187-200.

Hargreaves Heap, S. P. 1980. "Choosing the Wrong 'Natural' Rate: Accelerating Inflation or Decelerating Employment and Growth.” Economic Journal, 90(359): 611-20.

Hayek, Friedrich A. 1931. "Reflections on the Pure Theory of Money of Mr. J. M. Keynes.” Economica, 11(31): 270-95.

Hayek, Friedrich A. (1935) 1967. Prices and Production, 2nd ed. New York: Augustus M. Kelley.

Hendrickson, Joshua, and Alexander W. Salter. 2016. "Money, Liquidity, and the Structure of Production." Journal of Economic Dynamics and Control, 73: 314-28.

Honing, Ben, Michael Honing, John Morgan, and Ken Steiglitz. 2017. "Macroeconomic Effects of Credit Shocks: Loan Rigidities and System Memory." Working paper.

Horwitz, Steven. 2002. Microfoundations and Macroeconomics: An Austrian Perspective. London: Routledge.

Horwitz, Steven. 2010. "The Microeconomic Foundations of Macroeconomic Disorder: An Austrian Perspective on the Great Recession of 2008." Macroeconomic Theory and Its Failings: Alternative Perspectives on the Global Financial Crisis, ed. Steven Kates, 96-111. Aldershot, UK: Edward Elgar.

Horwitz, Steven G., and William J. Luther. 2011. "The Great Recession and Its Aftermath from a Monetary Equilibrium Theory Perspective." In The Global Financial Crisis: What Have We Learnt? ed. Steven Kates, 75-92. Cheltenham, UK: Edward Elgar.

Keeler, James P. 2001. "Empirical Evidence of the Austrian Business Cycle Theory." Review of Austrian Economics, 14(4), 331-51.

Kim, Chang-Jin, and Charles R. Nelson. 1999. "Friedman's Plucking Model of Business Fluctuations: Tests and Estimates of Permanent and Transitory Components." Journal of Money, Credit and Banking, 31(3): 317-34. 
Koppl, Roger. 2011. "Against Representative Agent Methodology." Review of Austrian Economics, 24(1): 43-55.

Koppl, Roger. 2014. From Crisis to Confidence: Macroeconomics after the Crash. London: Institute for Economic Affairs.

Koppl, Roger, and William J. Luther. 2012. "Hayek, Keynes, and Modern Macroeconomics." Review of Austrian Economics, 25(3): 223-41.

Layard, Richard, and Stephen Nickell. 1985. "The Causes of British Unemployment." National Institute Economic Review, 111(1): 62-85.

Layard, Richard, and Stephen Nickell. 1986. "Unemployment in Britain." Economica, 52(210): S121-S69.

Layard, Richard, and Stephen Nickell. 1989. "The Thatcher Miracle?" American Economic Review, 79(2): 215-19.

Layard, Richard, Baron Layard, and Stephen Nickell. 1991. Unemployment: Macroeconomic Performance and the Labour Market, ed. R. Jackman. Oxford: Oxford University Press.

Lester, Robert B., and Jonathan S. Wolff. 2013. "The Empirical Relevance of the Mises-Hayek Theory of the Trade Cycle." Review of Austrian Economics, 26(4): 433-61.

Lewin, Peter, and Nicolás Cachanosky. 2016. “A Financial Framework for Understanding Macroeconomic Cycles: The Time Structure of Production is Relevant." Journal of Financial Economic Policy, 8(2): 268-80.

Lewin, Peter, and Nicolás Cachanosky. Forthcoming a. "The Average Period of Production: History of an Idea." Journal of the History of Economic Thought.

Lewin, Peter, and Nicolás Cachanosky. Forthcoming b. "Value and Capital: Austrian Capital Theory, Retrospect and Prospect." Review of Austrian Economics.

Lucas, Robert E. 1972. "Expectations and the Neutrality of Money." Journal of Economic Theory, 4(2): 103-24.

Lucas, Robert E. 1973. "Some International Evidence on Output-Inflation Tradeoffs." American Economic Review, 63(3): 326-34.

Lucas, Robert E. 1975. "An Equilibrium Model of the Business Cycle." Journal of Political Economy, 83(6): 1113-44.

Lucas, Robert E. 1976. "Econometric Policy Evaluation: A Critique." CarnegieRochester Conference Series on Public Policy, 1(1): 19-46.

Lucas, Robert E. 1981. Studies in Business Cycle Theory. Cambridge, MA: MIT Press.

Luther, William J., and Mark Cohen. 2014. "An Empirical Analysis of the Austrian Business Cycle Theory." Atlantic Economic Journal, 42(2): 153-69.

Luther, William J., and Mark Cohen. 2016. "On the Empirical Relevance of the Mises-Hayek Theory of the Trade Cycle." Advances in Austrian Economics, 20: 79-103.

Luther, William J., and Alexander W. Salter. 2012. "Monetary Equilibrium and Price Stickiness Reconsidered: A Reply to Bagus and Howden." Review of Austrian Economics, 25(3): 263-69.

Mankiw, N. Gregory, and Ricardo Reis. 2002. "Sticky Information Versus Sticky Prices: A Proposal to Replace the New Keynesian Phillips Curve." Quarterly Journal of Economics, 117(4): 1295-1328.

Mankiw, N. Gregory, and Ricardo Reis. 2007. "Sticky Information in General Equilibrium." Journal of the European Economic Association, 5(2-3): 603-13. 
Minford, Patrick, and Ruthira Naraidoo. 2010. "Vicious and Virtuous Circles: The Political Economy of Unemployment." South African Journal of Economics, 78(1): $1-22$.

Mises, Ludwig von. (1912) 1953. The Theory of Money and Credit. New Haven, CT: Yale University Press.

Möller, Joachim. 1990. "Unemployment and Deterioration of Human Capital." Empirical Economics, 15(2): 199-215.

Nickell, Stephen. 1990. "Inflation and the UK Labour Market." Oxford Review of Economic Policy, 6(4): 40-61.

O’Driscoll, Gerald P., Jr. 2009. "Money and the Present Crisis." Cato Journal, 29(1): 167-86.

O’Shaughnessy, Terry. 2011. "Hysteresis in Unemployment." Oxford Review of Economic Policy, 27(2): 312-37.

Phelps, Edmund S. 1972. Inflation Policy and Unemployment Theory. London: Macmillan.

Price, Simon. 1992. "Human Capital, Hysteresis and Unemployment among Workers with Finite Lives." Scottish Journal of Political Economy, 39(2): 201-212.

Reis, Ricardo. 2017. "Is Something Really Wrong with Macroeconomics?” Working paper.

Rowthorn, Robert. 1995. "Capital Formation and Unemployment." Oxford Review of Economic Policy, 11(1): 26-39.

Salter, Alexander W. 2013. "Aggregates and Methodological Individualism: A Relational Approach." New Perspectives on Political Economy, 9(1): 5-23.

Salter, Alexander W. 2016. "Some Political Economy of Monetary Rules." Independent Review, 21(3): 443-64.

Salter, Alexander W. 2017. "Playing at Markets: A New Austrian Perspective on Macroeconomic Policy." Review of Austrian Economics, 30(1): 39-49.

Salter, Alexander W., and William J. Luther. 2016. "The Optimal Austrian Business Cycle Theory." Advances in Austrian Economics, 20: 45-60.

Salter, Alexander W., and Daniel J. Smith. 2017. "What You Don't Know Can Hurt You: Knowledge Problems in Monetary Policy." Contemporary Economic Policy, 35(3): 505-17.

Salter, Alexander W., and Vlad Tarko. 2017. "Polycentric Banking and Macroeconomic Stability." Business and Politics, 19(2): 365-95.

Sargent, Thomas. 1991. "Equilibrium with Signal Extraction from Endogenous Variables." Journal of Economic Dynamics and Control, 15(2): 245-73.

Schaffer, Matthew. Forthcoming. "Labor Market Effects in the Austrian Business Cycle Theory." Quarterly Review of Austrian Economics.

Selgin, George A. 2010. "The Futility of Central Banking." Cato Journal, 30(3): 46573.

Sessions, John G. 1994. "Unemployment Stigma and Multiple Labour Market Equilibria: A Social-Psychological Interpretation of Hysteresis.” Labour, 8(3): 355-76.

Stockhammer, Engelbert, and Simon Sturn. 2012. "The Impact of Monetary Policy on Unemployment Hysteresis." Applied Economics, 44: 2743-56.

Sturn, Simon. 2012. "Macroeconomic Policy in Recessions and Unemployment Hysteresis." Applied Economics Letters, 21(13): 914-17.

Wagner, Richard E. 2007. "Value and Exchange: Two Windows for Economic Theorizing." Review of Austrian Economics, 20(2-3), 97-103. 
Wagner, Richard E. 2010. Mind, Society, and Human Action: Time and Knowledge in a Theory of Social Economy. New York: Routledge.

Wagner, Richard E. 2012. "A Macro Economy as an Ecology of Plans." Journal of Economic Behavior and Organization, 82(2-3): 433-44.

White, Lawrence H. 2009. "Federal Reserve Policy and the Housing Bubble." Cato Journal, 29(1): 115-25.

White, Lawrence H. 2010. "The Rule of Law or the Rule of Central Bankers?” Cato Journal, 30(3): 451-63.

White, Lawrence H. 2016. "Hayek and Contemporary Macroeconomics." Advances in Austrian Economics, 21: 41-61.

White, Lawrence H., and George A. Selgin. 2017. "The Austrian Theory of the Business Cycle in a Fiat Money Regime." Working paper.

Young, Andrew T. 2005. "Reallocating Labor to Initiate Changes in Capital Structures: Hayek Revisited.” Economics Letters, 89(3), 275-82.

Young, Andrew T. 2011. "Illustrating the Importance of Austrian Business Cycle Theory: A Reply to Murphy, Barnett, and Block; A Call for Quantitative Study." Review of Austrian Economics, 24(1): 19-28.

Young, Andrew T. 2012. "The Time Structure of Production in the US, 20022009." Review of Austrian Economics, 25(2): 77-92. 